\title{
ON-FARM WATER ALLOCATION USING GIS-OWM MODEL IN THE NILE DELTA
}

\section{Abd Elwarth, N.A. ${ }^{1}$; Z.E. Ismail ${ }^{2}$; M.A. El-Adl ${ }^{3}$ and M.M. Ibrahim ${ }^{4}$ \\ ABSTRACT}

On-farm Water Allocation Module (OFWA) in GIS-OWM Model is considered as a decision support tool for water allocation. OFWA module helps to equity on water allocation among fields by generating dynamic maps. The GIS-OWM Model conducted during (1/10/2013 to 1/10/2014) in an area located in between Dakahlia and Kafr Elsheikh governorates, with net served area of 11795 Feddans. The water allocation dynamic maps can be generated based on gross irrigation water requirements calculations. In addition, the results indicated that, Irrigation field status dynamic maps among fields can be generated per hour during rotation ON-Times to illustrate the irrigation progress. The statistical analysis of the experimental location studies indicated that, there were a convergence between results of GIS-OWM consumed time to reach the selected gates and the actual measured time.

\section{NOMENCLATURES}

\section{$\mathrm{A}_{\mathrm{f}}$ : Canal served area (feddan) \\ $\mathrm{E}_{\mathrm{c}}$ : Conveyance efficiency $(\%)$,}

$\mathrm{GIR}_{\mathrm{f}}$ : Gross irrigation water requirements for field $\left(\mathrm{m}^{3}\right)$,

$\mathrm{Q}_{\mathrm{f}}$ : Amount of water determined for feddan $\left(\mathrm{m}^{3}\right)$

$\mathrm{n}$ : roughness and irregularities of the channel,

$\mathrm{T}_{\mathrm{c}}$ : Time to reach a gate at the same segment ( $\mathrm{s}$ )

$\mathrm{T}_{\mathrm{f}}$ : Field's finishing irrigation time (s)

$\mathrm{T}_{\mathrm{s}}$ : Time to reach the end of the segment (s)

$\mathrm{V}_{\mathrm{s}}$ : Water velocity through the segment $(\mathrm{m} / \mathrm{s})$,
$\mathrm{D}_{\mathrm{g}}$ : Gross irrigation water depth (mm)

GIR: Gross irrigation water requirements $\left(\mathrm{m}^{3}\right)$,

S: Slope of the water surface or the linear hydraulic head loss $(\mathrm{m} / \mathrm{m})$

$\mathrm{Q}$ : Water resource discharge $\left(\mathrm{m}^{3} / \mathrm{sec}\right)$

$\mathrm{N}$ : Manning coefficient,

$\mathrm{T}_{\mathrm{g}}$ :Time to reach each gate at the network, $\mathrm{s}$

$\mathrm{T}_{\mathrm{fs}}$ : Field's starting irrigation time (sec)

$\mathrm{V}$ : average water velocity, $(\mathrm{m} / \mathrm{s})$

R: Hydraulic radius.

\footnotetext{
${ }^{1}$ Agricultural Engineer in, Agric. Eng. Res. Institute (AEnRI) - El-Dokki, Cairo.

${ }^{2}$ Prof. of power technology and form machinery, Agric. Eng. Dept., Mansoura Univ.

${ }^{3}$ Prof. of Agric. Eng. Dept., Faculty of Agric., Al-Mansoura Univ.

${ }^{4}$ Assistant Prof. of Agric. Eng. Dept., Faculty of Agric., Al-Mansoura Univ.
} 


\section{INTRODUCTION}

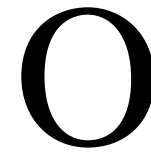
$\mathrm{n}$-Farm Water Management is considered as an indicator to irrigation water storage, water distribution at the channel level, water delivery at the plot level, monitoring and evaluation (Gundogdu et al.-2003). While, Benli et al. (2005) indicate the ways to achieve effective water management that optimized irrigation scheduling for different crops, optimized crop patterns for farms, and efficient water allocation for water networks. EL-Banna and Ismail (1994) designed a program to evaluate water amount factors affected predict of evaporation and evapotranspiration from the data collected from 19 wither stations at Egypt. Wen et al. (2004) developed a GIS based model framework for regional irrigation water demand assessment. It is a tool for improving demand planning by setting up different scenarios and revealing the impacts under those scenarios to search for the one with the least negative impact. Ismail (2001) investigated a sensor to open and close the input water gate for passing a required amount of water discharge. Bustamante et al. (2007) developed a tool using spatial information system to improve water management in Mexico. The tool used to forecast seasonal water demands at the beginning of each water year and generating maps of field irrigation status. The types of these maps were in-progress, future and postponed. Postponed maps were divided into two subtypes; delay and urgent irrigation. Manna (2000) developed a GIS-based irrigation scheduling and on-farm water allocation (OFWA) program for irrigated crops. Water is allocated to the fields based on this priority setting, water availability and irrigation system constraints. The GIS program will automatically transfer the fields that left without irrigation to the next day. Wong (2004) developed a model for water allocation using GIS included water allocation scenarios that created based on the demands of the crops grown on fields and the available water supply for agriculture within the watershed. Ramadan et al. (2015) developed a GIS-based decision support model for On-farm Water Management (GIS-OWM model). That model includes three modules for water requirements calculations, crops manipulation and On-farm Water Allocation (OFWA).

The main objective of this study is developing a module into GIS-OWM Model for optimal OFWA to ensure equity in water allocation among the fields, and conducting the module for the study area in the Nile Delta. 


\section{METHODOLGY}

The location of study area in Egypt was $31.22^{\circ}-31.33^{\circ} \mathrm{N}$ and $31.23^{\circ}$ $31.3^{\circ} \mathrm{E}$. It is in between Dakahlia and Kafr Elsheikh governorates, with net served of 11795 feddans (4954 ha). The main water resource comes from the river Nile. Water is distributed via the rotational systems among sub canals. The area contains sub canal (Bahr Elbeshma) and its six distributaries. The net served area for the canals: Bahr Elbeshma (direct irrigation), Seryowa, Elshtoot, Habeeb, Alkomsewon, Elkatf, and Roos Elferakh are 4078.0, 976.10, 1175.68, 1033.75, 1864.27, 1743.42 and 923.75 feddans respectively. Under these areas rice, cotton, maize and vegetables are cultivated in summer season and wheat, clover, sugar beet, potatoes, fababean, and flax are winter crops. The area is classified as an arid region because the rainfall varies from as minimum as $0.0 \mathrm{~mm}$ in July to a maximum of $40 \mathrm{~mm}$ in January.

One of the main challenges for farmers in Nile Delta that water is not available permanently during seasons. The major problem of area is water shortage in several zones especially at ends of canals.

\section{On-farm Water Allocation Module (OFWA)}

OFWA Module is the third module in GIS-OWM that developed by Ramadan et al. (2015). The first module "irrigation water requirements calculations" output is the gross irrigation water depth for each crop. The second module "Crops manipulation" aims to manipulate an optimal crops pattern that insures the amount of total water would be allocated among crops during the season doesn't exceed the available water amount carried by the canal. The output that obtained from first module is used in second and so on the third module.

The OFWA module considered as a decision support tool for water allocation. In this module, dynamic maps for field irrigation status and OFWA are generated. The OFWA dynamic maps demonstrate the total gross irrigation water required for fields during the ON Time. The field irrigation status dynamic maps illustrate the irrigation status during the ON Time (irrigated / in-progress / non-irrigated) refers to the fields already have finished; fields are still in irrigation progress, and fields that not been irrigated yet. These maps are determined according to the starting and the 
finishing irrigation time for every field. The starting or finishing irrigation time added to time started. The following steps for generating the dynamic maps:

\section{Step 1 - Gross irrigation water requirements for fields $\left(\mathbf{G I R}_{f}, \mathbf{m}^{\mathbf{3}}\right)$}

The $\mathrm{GIR}_{f}$ for a field was estimated according to the original standard by the following equation:

$$
\mathrm{GIR}_{f}=\mathrm{D}_{\mathrm{g}} \times \mathrm{A}_{\mathrm{f}} \times \text { Constant }
$$

Gross irrigation water depth " $\mathrm{D}_{\mathrm{g}}$ " for all crops was estimated using first module into GIS-OWM. Crops were allocated spatially using second module (crops manipulation). Suggested new pattern was also saved into the geo-database. The OFWA dynamic maps could be generated after this step.

\section{Step 2 - Water velocity Calculation}

Manning's equation is used in determining the average velocity $(\mathrm{V}, \mathrm{m} / \mathrm{sec})$ in a canal segment section according to Ali (2011),

$$
V=\frac{1}{n} R^{\frac{2}{3}} S^{\frac{1}{2}}
$$

Where; the value of $\mathrm{n}$ indicates not only the roughness of the sides and bottom of the channel, but also other types of irregularities of the channel, such as alignment and vegetation. Average water velocity calculation was applied using field calculator tool on the canal segments feature class.

\section{Step 3 - Determining the distance between gates and beginning of segments}

Distance between each gate (350 gates) and the beginning of the segment was determined on the canal segments layer separately by measurement on the map. The tallest distance between two gates was $1.178 \mathrm{~km}$ and the shortest was $6.4 \mathrm{~m}$. The average of the distance was $112 \mathrm{~m}$.

Canals lines divided into 16 segments based on the bed width and water surface sloping. Bahr Elbeshma, Alkomsewon and Seryowa canals divided into seven, three and two segments respectively and each other canal was considered as one segment (according to the ministry of water resources and irrigation- Figure - 1). 


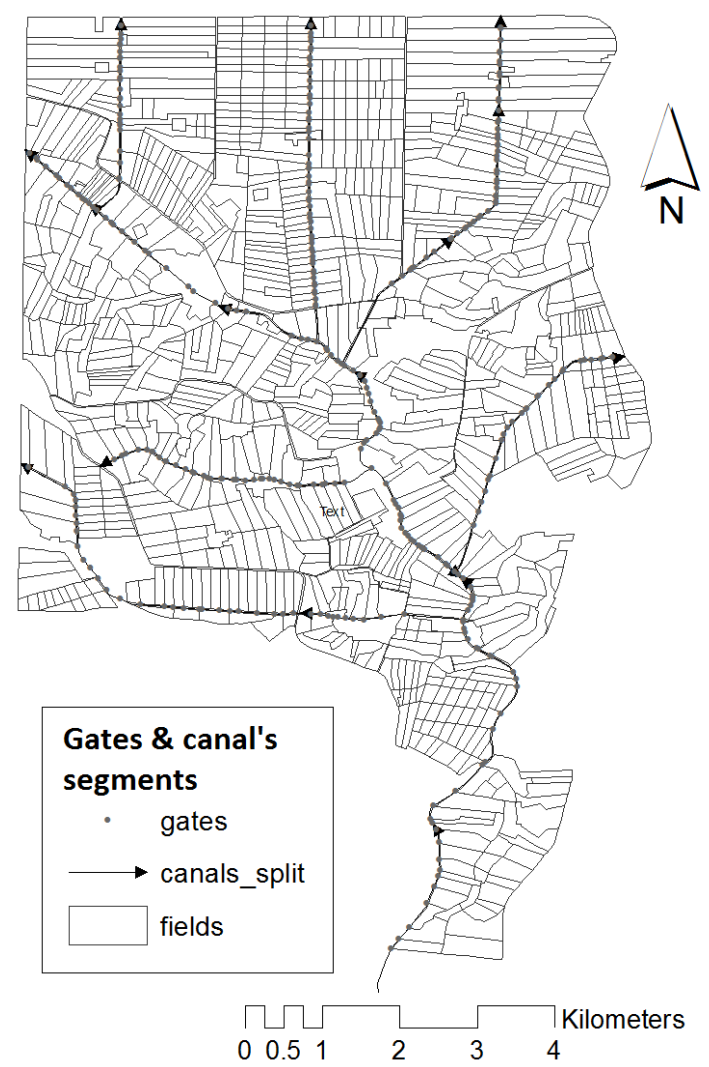

Figure (1): Segments and gates distribution

Step 4 - Consumed flow time to reach each gate at the network $\left(T_{g}\right)$

The consumed flow time to reach each gate at the network $\left(\mathrm{T}_{\mathrm{g}}\right)$ is calculated by the following equation:

$$
T_{g}=\sum\left(\mathrm{T}_{\mathrm{S} 1}, \mathrm{~T}_{\mathrm{S} 2}, \ldots . \mathrm{T}_{\mathrm{Sn}}, \mathrm{T}_{\mathrm{c}}\right)
$$

Where; $\mathrm{sn}=$ Number of the segment. In addition, the consumed flow time between the beginning of the segment and the gate $\left(\mathrm{T}_{\mathrm{c}}\right)$ estimated according to the original standard by the following equation:

$$
T_{c}(\mathrm{Sec})=\frac{L}{V_{s} \times E_{c}}
$$

Where; L: Distance between the gate and the beginning of the segment $(\mathrm{m})$, Conveyance efficiency $\left(E_{C}\right)=75 \%$, based on assumption according to Brouwer et al. (1989). The consumed flow time through the segment $\left(T_{S}\right)$ is calculated by equation (4) where L: the length of the segment. 


\section{Step 5 - Field's finishing irrigation time $\left(T_{f}\right)$}

Time to finish irrigation for a field $\left(T_{f}\right)$ is calculated by following equation:

$$
T_{f}=\frac{G I R_{f}}{Q}
$$

Step 6 - Time to start irrigation for a field $\left(\boldsymbol{T}_{f s}\right)$

Time to start irrigation for a field $\left(T_{f s}\right)$ from the beginning of ON Time is calculated according to following equation:

$$
T_{f s}=\sum\left(T_{g}, T_{f 1}, T_{f 2}, \ldots . . T_{f n}\right)
$$

Where; $f n$ : field irrigation sort into the district. The district is a group of fields has the same gate.

The ArcMap 10.1 utilizes to perform the integration between GIS and On-Farm water management. The model developed using Arc Objects NET 10.1 SDK and Microsoft Visual Studio 2010 (C $C^{\#}$ Language).

\section{RESULTS AND DISCUSSIONS}

\section{On-Farm Water Allocation Module Verification}

The GIS-OWM calculated consumed time to reach selected gates on Bahr Elbeshma canal was verified by the actual consumed time to reach the same gate. The actual time was calculated based on the measured velocity by the average velocity flow probe. Figures (2.A) illustrates the relationships between in-gates distance $(\mathrm{m})$ and the actual consumed time (minutes) until to reach to selected gates on Bahr Elbeshma canal, while figure (2.B) recorded the same in-gate distance and the consumed time to reach the same gates using GIS-OWM model. As shown in the Figures, the value of the regression line slope for the actual measured time is nearly to the slope for the GIS-OWM time $(0.0448 \cong 0.0416)$. On the other hand, the regression coefficient $\left(\mathrm{R}^{2}\right)$ values were 0.962 and 0.9857 for the actual time and GIS-OWM time, respectively. While, the regression correlation coefficient $(\mathrm{R})$ values were 0.98 and 0.99 for the actual time and the GIS-OWM time, respectively.

According to the analysis of deviation, the values of standard deviation for the actual time and GIS-OWM time were 27.4 and 31.9 respectively. In addition, the standard error was 7.6 for the actual time and 8.85 for the GIS-OWM time. So there is convergence between results of GIS-OWM consumed time to reach the selected gates and the actual measured time. 

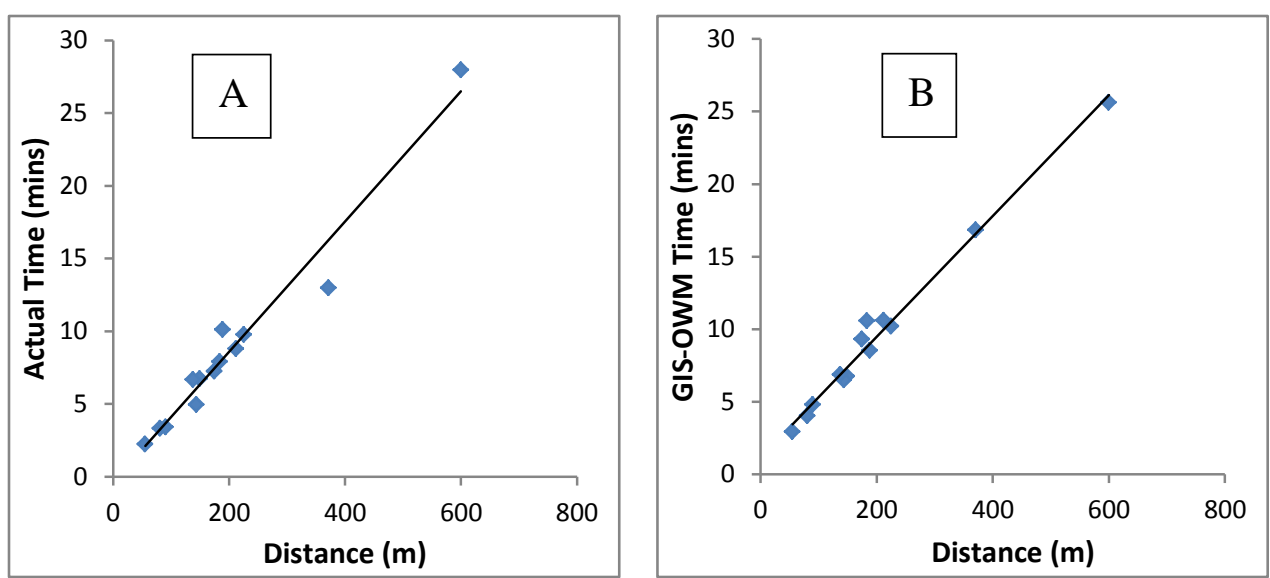

Figure (2): The relationships between the distance among gates (m) and each of actual consumed time (mins) (A) and calculated from GISOWM model (mins) (B).

\section{Dynamic maps for On-farm Water Allocation}

GIS-OWM dynamic maps for OFWA generated for all rotations separately and they including the estimated gross irrigation requirements for each rotation. For example, figure (3) shows the forecasted On-farm Water Allocation (OFWA) dynamic maps for rotations No. 6 (the period between: 22/12/2013 to 26/12/2013) and No. 21 (29/6/2014 to 3/7/2014). The crops that required water on rotation No. 6 were autumn potato, flax, fababean, sugar beet, and clover. There were 9170.8 feddans required that required $2.2 \times 10^{6} \mathrm{~m}^{3}$ of water. While, there are 2624.2 feddans did not require water in this rotation.

As shown in figure (3.A), the highest gross irrigation requirements (GIR) that was estimated during rotation No. 6 were $354 \mathrm{~m}^{3}$ per feddan and the least was $154 \mathrm{~m}^{3}$ per feddan. There were 1442.1 feddans required $354 \mathrm{~m}^{3}$ of water per feddan. However, there were 719 feddans required $154 \mathrm{~m}^{3}$ of water per feddan. There were 2289, 3884, 836.7 feddans, respectively required $287,216,166 \mathrm{~m}^{3}$ of water per feddan, respectively.

Otherwise, the crops that required water on rotation No. 21 were rice, maize, and cotton. Under this ration there were 9121.3 feddans that required $2.76 \times 10^{6} \mathrm{~m}^{3}$ of water and the total saved water amount was $1.84 \times 10^{5} \mathrm{~m}^{3}$ during this rotation. While, there were 2674 feddans did not require water in this rotation. Figure (3.b) shows that the greatest gross irrigation 
requirements (GIR) that were estimated during rotation No.21 was $503 \mathrm{~m}^{3}$ per feddan and the least was $195 \mathrm{~m}^{3}$ per feddan. Also, there were 3686 , 2533.3 and 2902 feddan, respectively required 195,228 , and $503 \mathrm{~m}^{3}$ of water per feddan respectively.

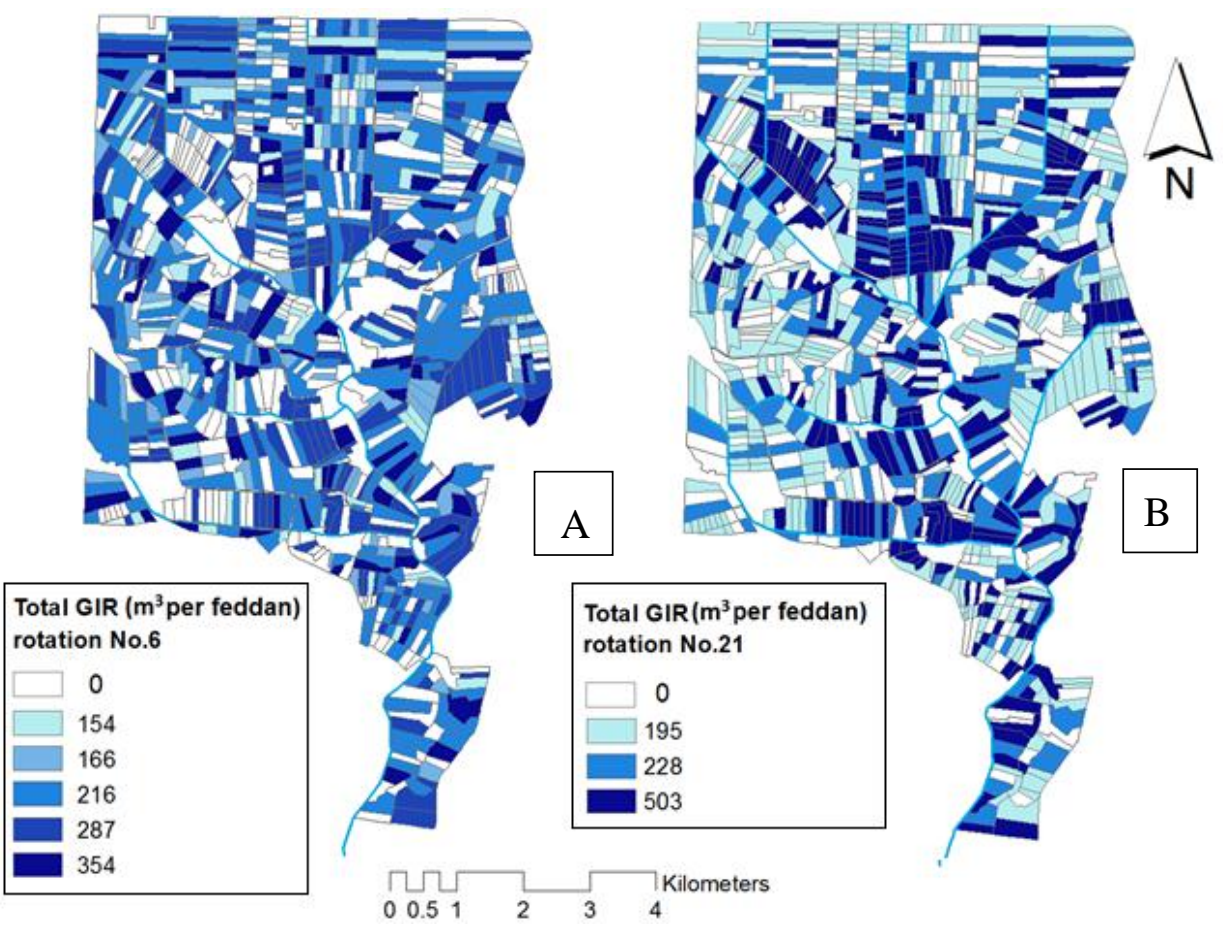

Figure (3): GIS-OWM On-farm Water Allocation dynamic map A-Rotation NO. 6.

B-Rotation NO.21.

Figure (4) shows the estimated amount of water using the GIS-OWM for the seven canals, the total available water amount (TCAW, $\mathrm{m}^{3}$ ) and the saved water amount $\left(\mathrm{m}^{3}\right)$ during Rotation No.21. The GIS-OWM TGIR, TCAW and total saved water for the served areas that irrigated directly from Bahr elbeshma canal were $9.46 \times 10^{5}, 1.02 \times 10^{6}, 7.39 \times 10^{4} \mathrm{~m}^{3}$ respectively. However, the GIS-OWM TGIR, TCAW and total saved water for the amounts of water carried by Bahr elbeshma canal for total served area were $2.76 \times 10^{6}, 2.94 \times 10^{6}$, and $1.84 \times 10^{5} \mathrm{~m}^{3}$ respectively.

\section{Dynamic maps of field irrigation status}

The dynamic of field irrigation status maps are generated using the Onfarm Water Allocation (OFWA) module. The maps illustrate the irrigation status for fields during the ON-Time (non-irrigated / in-progress 
/ irrigated) and it could be changed every one hour. Figures (5 and 6) show the dynamic field irrigation status maps during rotation No.10 (from 20 Feb. 2014 to 23 Feb. 2014). The amount of water that required during this rotation was $2.2 \times 10^{6} \mathrm{~m}^{3}$ for 8064 feddans.

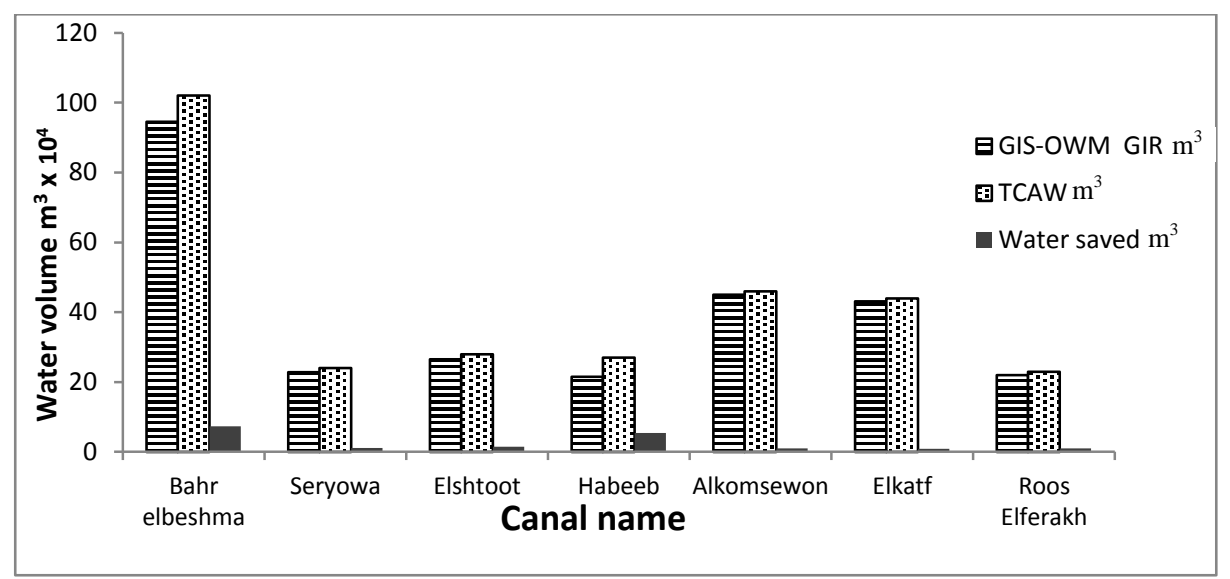

Figure (4): Irrigation water allocation using GIS-OWM among the canals on rotation NO. 21

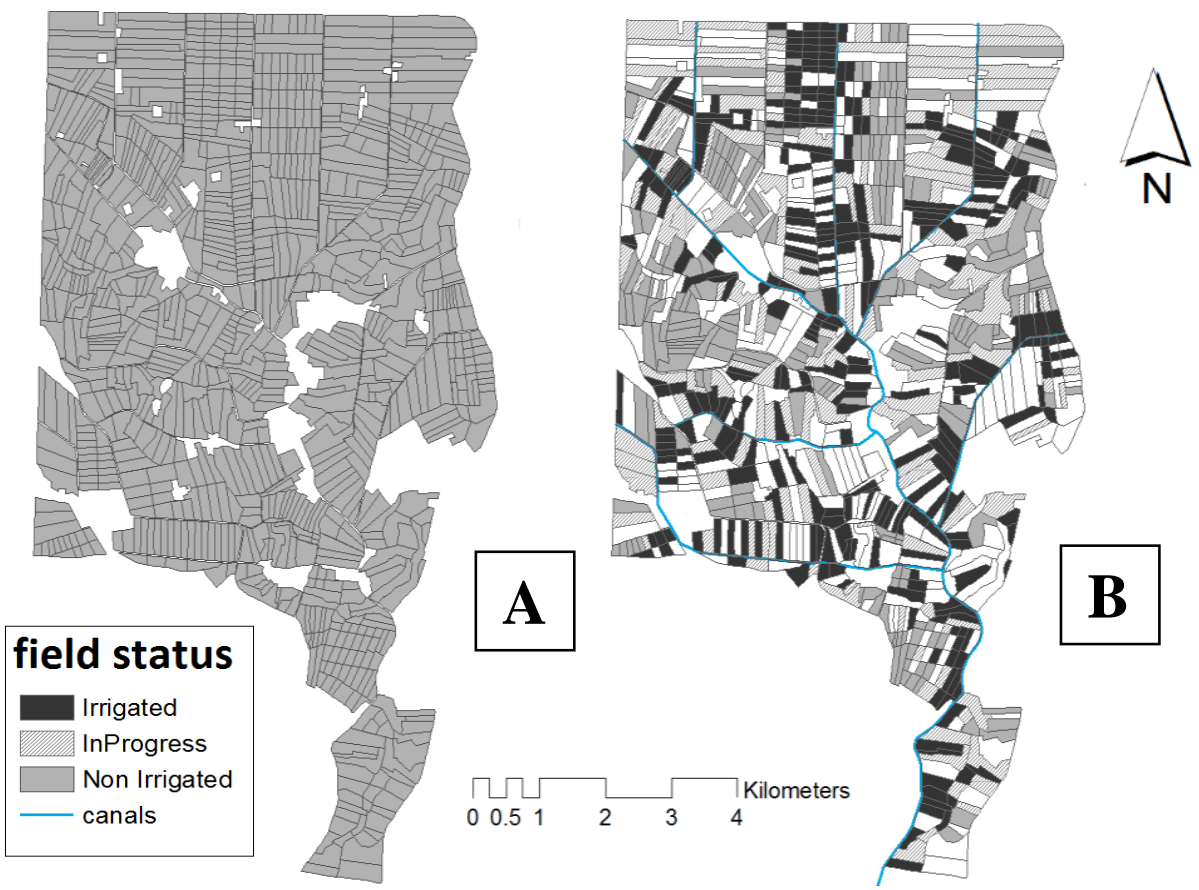

Figure (5): GIS-OWM for field irrigation status dynamic map on (A) 20 Feb. at 6 pm, (B) $21 \mathrm{Feb}$ at 6 am 

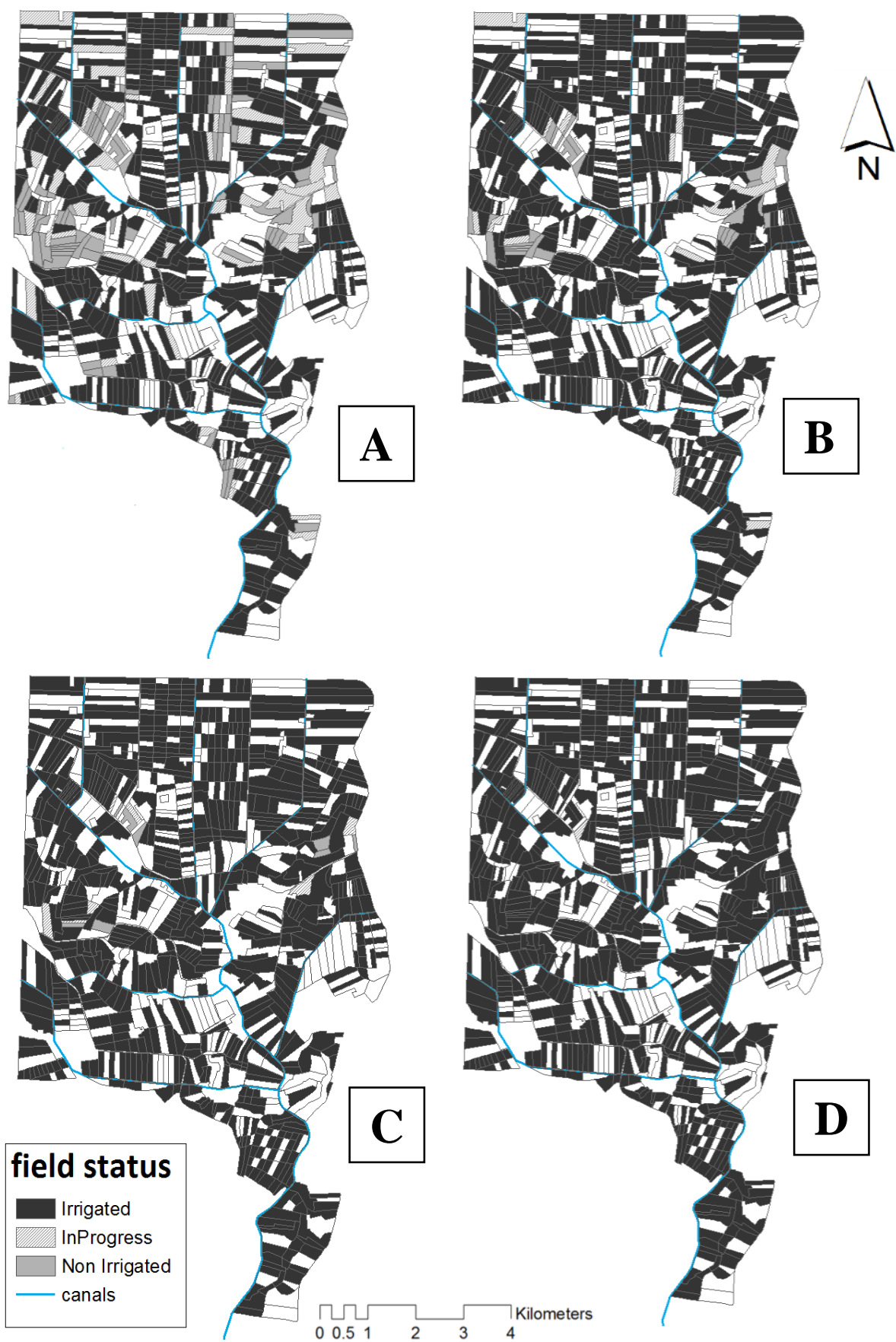

Figure (6): GIS-OWM for field irrigation status dynamic map on; (A) 21 Feb. at 18 am, (B) 22 Feb. at 6 pm, (C) 22 Feb at 18 pm, (D) 23 Feb. at 6 am. 
Figure (7) illustrates the area for fields that non- irrigated, in-progress, and irrigated per 6 hours. For example, at 12 am on 22 Feb. 2014, there were 515.7 feddans non-irrigated, 687 feddans in progress, and 6861 feddans irrigated. After 6 hours at 6 am, the areas changed to 278 feddans non-irrigated, 298 feddans in progress, and 7488 feddans irrigated.

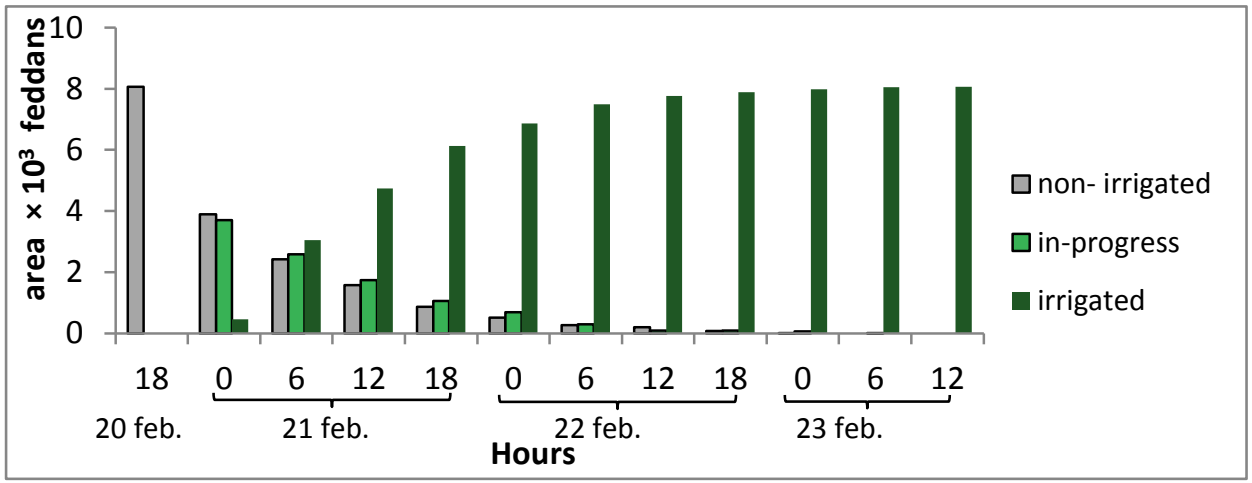

Figure (7): Areas per (feddans) for field irrigation status per 6 hours

Moreover, figure (8) illustrates the volume of water for fields that nonirrigated, in-progress, and irrigated per 6 hours. For example, at 12 am on 22 Feb. 2014, there were $1.39 \times 10^{5} \mathrm{~m}^{3}$ for non-irrigated fields, $1.94 \times 10^{5} \mathrm{~m}^{3}$ for in progress fields, and $1.87 \times 10^{6} \mathrm{~m}^{3}$ for irrigated fields. After 6 hours at $6 \mathrm{am}$, the water volumes changed to $7.5 \times 10^{4} \mathrm{~m}^{3}$ for nonirrigated fields, $8.28 \times 10^{4} \mathrm{~m}^{3}$ for in progress fields, and $2.0 \times 10^{6} \mathrm{~m}^{3}$ for irrigated fields.

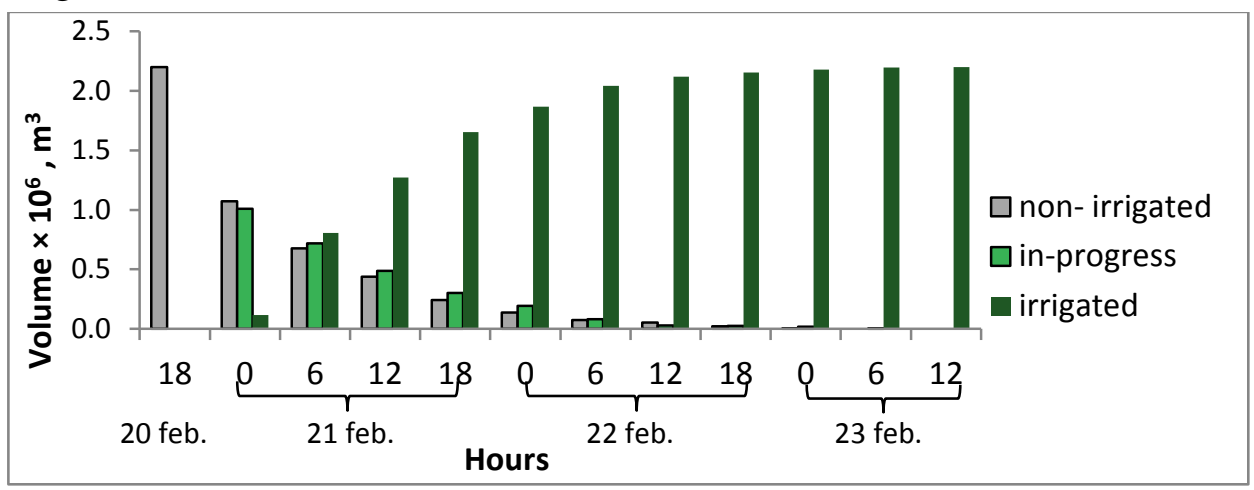

Figure (8): Water volume $\left(\mathrm{m}^{3}\right)$ for field irrigation status per 6 hours

It is noticed from figures (5), (6), (7), and (8) that in the start of the rotation, changing in field irrigation status was faster than the other days on the rotation. This occurred because fields cultivated with wheat and 
clover started irrigation at $20 \mathrm{Feb}$. However, fababean and potatoes started at $22 \mathrm{Feb}$. On the other hand, fields with flax were irrigated at 23 Feb. the net area of wheat, clover, fababean, potatoes, and flax were 2079, $3884,719,545$ and 837 feddans respectively required in this rotation $6.73 \times 10^{5}, \quad 9.12 \times 10^{5}, \quad 2.42 \times 10^{5}, \quad 1.03 \times 10^{5}, \quad 2.67 \times 10^{5} \mathrm{~m}^{3}$ of water respectively.

\section{CONCLUSIONS}

GIS-OWM model is a GIS-based decision support model was developed for On-farm Water Management by Ramadan et al. (2015). The third module "On-farm Water Allocation" (OFWA) helps to equity on water allocation among fields by monitoring field status and generating dynamic maps for On-farm Water Allocation (OFWA) and field irrigation status fot the study area during the period between 1/10/2013 to $1 / 10 / 2014$.

Water allocation dynamic maps among fields were generated for rotations no 6 and 21. The greatest gross irrigation requirements were 354 and 503 $\mathrm{m}^{3}$ per feddan. However the least were 154 and $195 \mathrm{~m}^{3}$ per feddan respectively. The OFWA map for rotation no.21 in summer season illustrates that the total saved water amount from the available water during this rotation were $1.84 \times 10^{5} \mathrm{~m}^{3}$. On the other hand, field status dynamic maps are generated every hour to illustrate the irrigation progress. The maps show the fields already have irrigated, the fields are still in irrigation progress, and fields that have not been irrigated yet. The maps for rotation no. 10 illustrated that changing in field irrigation status in the start of the rotation was faster than the other days in the rotation. This occurred because area that required irrigation in first 3 days were more than fields that required irrigation in other days.

\section{REFERENCES}

Ali, M. H. 2011. Practices of Irrigation and On-farm Water Management. Volume 2. Springer. New York. USA. 546 P.

Benli, B.; S. Kodal, T. Oweis, and A. Ilbeyi. 2005. A model for optimum water allocation with adequate and limited water supplies. The international workshop on Water, Land and Food Security in Arid and Semi-arid, CHIEAM-IAMB Bari, Italy, September 6-11. PP. 1-10. 
Brouwer, C.; K. Prins and M. Heibloem. 1989. Irrigation water management: Irrigation scheduling Training manual No. 4, FAO, Rome, Italy. Available at http://www.fao.org/docrep/T7202E/T7202E00.htm Accessed on Jan.2014.

Bustamante, W. O.; J. M. G. Camacho; E. S. Ibarra; E. Isidro and L. R. Pimentel. 2007. Using spatial information systems to improve water management in Mexico. Agricultural Water Management Journal. Vol. No. 89: pp. 81 - 88.

El-Banna, E. B. and Z. E. Ismail. 1994. Meteorological data affecting evapotranpiration for water blanca equation. J. Agric. Sci. Mansoura U. 19 (10): 3389-3408.

Gundogdu, K.S.; H. Degirmenci and C. Demirtas. 2003. Creation of GIS supported database in irrigation project management. Proceedings of AGRO-ENVIRON, the 3rd International Symposium on Sustainable Agro-Environmental Systems: New Technologies and Applications, Cairo, Egypt. October 26-29. 6 P.

Ismail, Z.E. 2001. Electrical sensor of soil moisture content. J. Agric. Sci. Mansoura Univ. 26 (11): 7269-7278.

Manna, S. D. 2000. GIS - Based Irrigation Scheduling and On Farm Water Allocation. Unpublished. Ph.D. thesis. Chemical and Bioresource Engineering Dept. Univ. Colorado State. Fort Collins, Colorado. USA. $123 \mathrm{P}$.

Ramadan, M.H.; M.M. Ibrahim and N. A. Abd Elwarth. 2015. Irrigation Water Management In The Nile Delta Using GIS Technology. Misr Journal of Agricultural Engineering. Vol. No. 32(4): pp. 1503 - 1528.

Wen, T. H.; M. D. Su and Y. L. Yeh. 2004. A GIS-based framework of regional irrigation water demand assessment. Paddy and Water Environment Journal. 2 (1): 33-39.

Wong, A. W. 2004. Spatial Allocation of Irrigation Water in an Agricultural Watershed Using GIS. Unpublished M.Sc. thesis. Fac. of Graduate Studies. Guelph Univ. Canada. 169 P. 


\section{الملخص العربي}

\section{توزيع مياة الري الحقلى في دلتا النيل بإستخدام (GIS-OWM)}

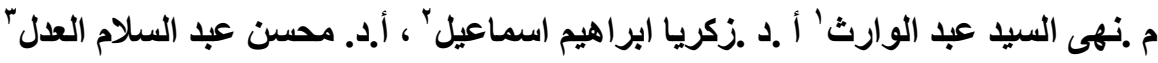

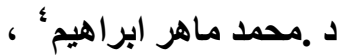

برنامج (GIS-OWM) هو برنامج لدعم اتخاذ القرار فى عملية إدارة مياه الري باستخدام تقنية

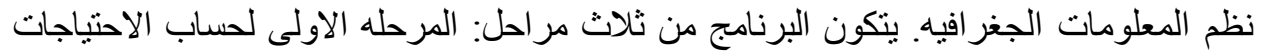

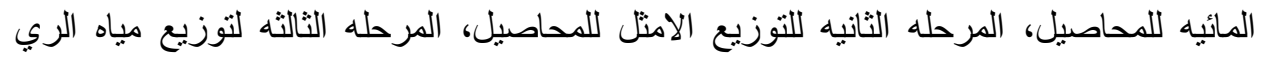

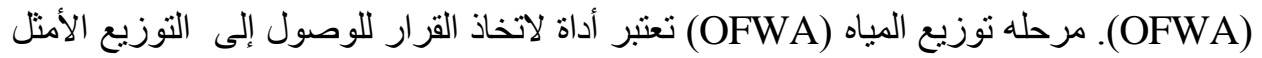
العادل للمياه. تتيح هذه المرحلة للمستخدم بمساعده البيانات المخزنه في المرحلتين الأولى والثانية التئية

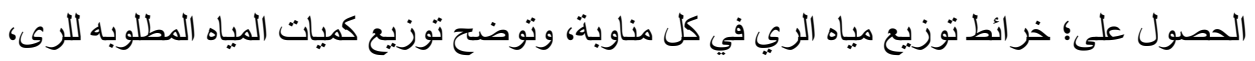

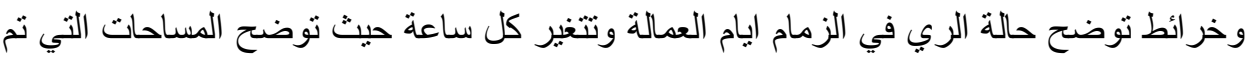
ريها والمساحات التي لاز الت في عملية الري و المساحات التى لم يتم ريها بعد. تم تقييم المرحلة

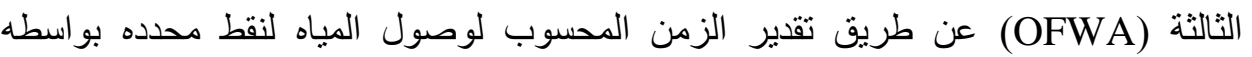

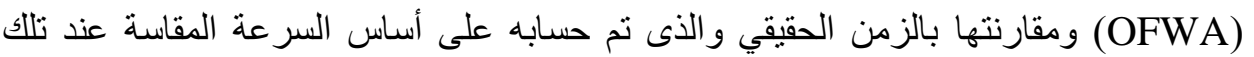
النقط بو اسطه جهاز قياس سر عه المياه في القتوات (Overage Velocity Flow Probe). حيث اثبتت الطرق الاحصائيه تقارب البيانات بينهما. تم عمل در اسة حاله للبرنامج على منطقة واقعه بين محافظتي الدقهلية وكفر الثيخ تحتوي ترعة

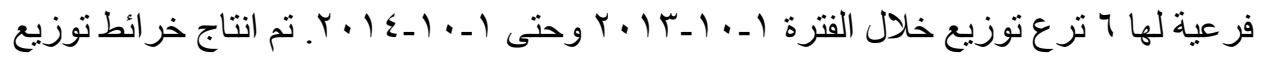

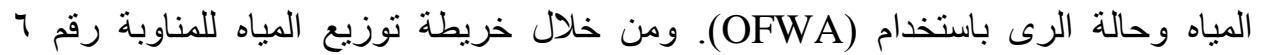

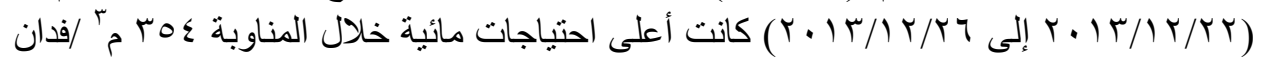

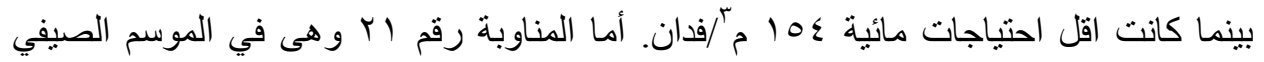

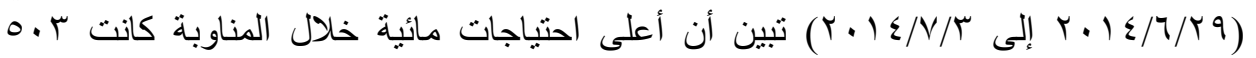

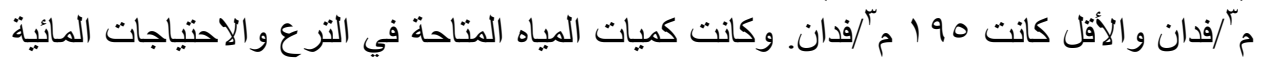
الكلية للمحاصيل الموزعة باستخدام (GIS-OWM) و كميات المياه المتوفرة في هذه المناوبة

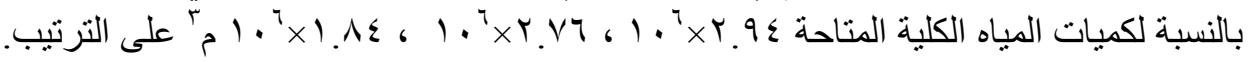

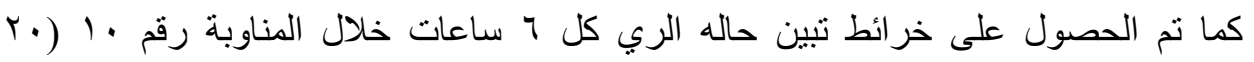

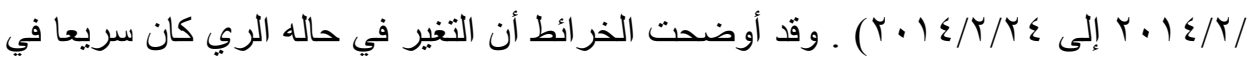

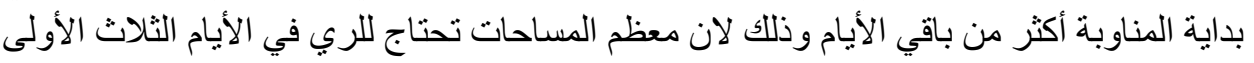

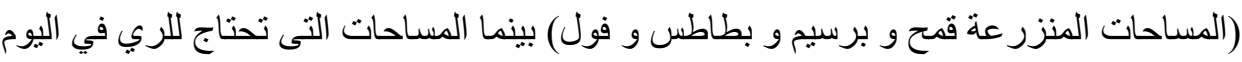

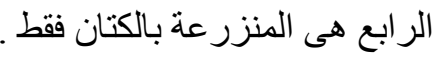

' أخصائي زراعى بمعه بحوث الهندسه الزراعيه بالدقى، الجيزه.

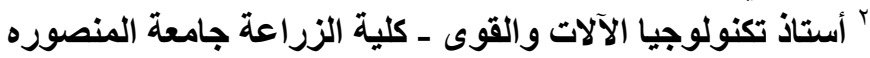

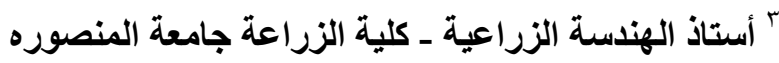

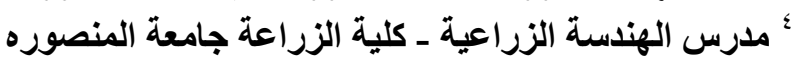

